\title{
Purification and Characterization on an Antibacterial Agent from (Eugenia Caryophllate) Against of Some Pathogenic Bacteria Isolated From Fishes \\ Doaa A. El-Araby
}

Fish Health and Management Dept., Central Laboratory for Aquaculture Research (CLAR), Abbassa, Sharkia, Egypt.

\begin{abstract}
Local bacterial cultures could be isolated from 200 Oreochromis niloticus and were caught as random samples from ELAbassa, AbouHammad, and Sharkia, Egypt. Fish farms with an average body weight $40 \pm 5 \mathrm{~g}$. Suffered From signs of septicemia as hemorrhages on several parts of the body surface (mouth) base of fins, abdominal part. opercula, and around the anal opening turbidity of the eyes and slight exophthalmia roughness of scales and sometime scale losses, postmortemally showing, hepatomegaly, splenomegaly, congestion of gills, kidney and accumulation, of bloody fluid in abdominal wall to bacterial strains are Gram negative bacteria were isolated from fish. The bacterial isolate taxonomic classification clarified that the bacterial isolates was likely belonging to Pseudomonas aeruginiosa-I, Aeromonas hydrophila-2 according to its physiological morphological, and biochemical characters. The active extract using bioactivity-guided technique of aqueous and organic extracts of (Eugenia caryophllate). The separation of the active ingredient and its purification was performed using both thin layer chromatography (TLC) and column chromatography techniques. The physico-chemical characteristics of the purified antibacterial agent viz. color, melting point, solubility, elemental analysis and spectroscopic characteristics ( $\mathrm{GC}$ - mass techniques) have been investigated. This analysis indicates a suggested empirical formula of $\mathrm{C}_{10} \mathrm{H}_{12} \mathrm{O}_{2}$. The biological activities i.e. MICs of the Purified antibacterial agent were also determined.
\end{abstract}

Keywords: Aeromonas hydrophila, MIC, Antibacterial, Fish

\section{Introduction}

Antimicrobial substance as one of new widely used for the treatment of bacterial diseases of fish. Fish diseases due, to bacterial infection are considered one of the major problems in aquacultures (Okpk Warsill, 1991; Robertson, 2000; Eid et al, 2016). The presence of potential danger of many fish pathogens associated with the .stress factors may favor the 
occurrence of outbreaks in cultured fishes caused by Pseudomonas considered to be the major bacterial problems facing the aquaculture development causing mass mortalities, reduced production and low quality of aquatic organisms (Ghittino, 1976) P. aeruginosa and Aeromonas hydrophila were incorporated in sever outbreaks among fish tilapia's hatcheries (Ahmed and Shoreit, 2001; Ali Aberoum, 2010; Yardimci, 2011; Ye, 2013 and Abouelmaatti et al, 2012) To treatment fish diseases (bacterial infection) can used antibiotics, but its cause's chinning in environmentals conditions such as ppt the resin and the toxins in fishes and become toxicity in the nutrition to the human or the animals. One of the most recent concepts is replacing the chemical and therapeutic agents with natural components as one of the strategies available and much experimental work is being carried out to assess its commercially applicability (Kosar et al.,2005; El-Didamoy et al., 2015 and Elfeil et al, 2012). Eugenia caryophllate plants belonging to different species and ecotypes (Biotypes) are widely used in in several industries as it has a flavor and cosmetically in pharmaceutical, beverage and food industries. It has also used been as a traditional remedy to treat various ailments such as a spasmodic, antimicrobial, expectorant, carminative and aromatic for whooping and convulsive coughs, digestive disorders and menstrual problems (Aligiannis et al., 2001). In previous studies, it has been demonstrated that the content of essential oil and extracts of medicinal plants like eugenia caryophllate species containing antibacterial activities on many bacteria (Sahin et al., 2004 and Reverter et al., 2014) antioxidant and other biological activities may change based on the deference's in cultivation, origin, vegetative stage and growing seasons of the plants (Deans et al., 1992 and Milos et al., 2000). The chemical compositions of eugenia caryophllate are Eugenol \& phenol (Sahin et al., 2004) and (Sivasalnkar et al., 2015). This study aims to isolate and identify the most common bacterial Fish pathogens and extract and purification of antibacterial bioactive secondary metabolite product of eugenia caryophllate.

\section{Material and methods}

Isolation and Purification of bacterial pathogen from Fishes:

Total number of 200 Oreochromis niloticus showing signs of septicemia collected from central laboratory for aquaculture research and submitted to fall clinical examination postmortem examination and bacteriological examination according to (Schapercluas et al., 1992). Samples for bacteriological examination taken from affected Fishes from (Skin, fins, muscles, liver, spleen, kidney, intestine, 
and gills under aseptic condition loopful from each organ inoculated into nutrient broth, incubated at 28- $30^{\circ} \mathrm{C}$ For 24 h., then after streaked on plates of nutrient agar and incubated at $28-30^{\circ} \mathrm{C}$ for 24 hrs. It was purified using the streaking plate technique method as recorded by Williams and Davis (1965)

Identification of Bacterial isolates:

Morphological characteristics:

Morphological characteristics of colonies colour, Gram reaction. Cell Shape, Spore formation, and Motility and Diffusible pigment were investigated.

Physiological and biochemical characteristics of pathogenic bacterial isolates were conducted according to Elwan, et al. (1977), Lipase; Ammar, et al. (1991), Protease; Ammar, et al. (1995), Pectinase; Ammar, et al. (1998), aamylase On the other hand, Lecithinase was conducted on egg yolk medium according to the method of Nitsh and Kutzner (1969) and Catalase Test. Esculine broth has been done. Nitrate reduction was performed. Hydrogen sulphied; poly $\beta$ - hydroxyl butyrate accumulation. King A \& B, Methyl red, Voges-Proskauer, indol production. Urea test, Gelatein liquefaction, Levan formation, Arginine dihydrolase, Malonate utilization, Phenyl alanine deamination. Utilization of $\mathrm{KCN}$, oxidase test and different carbon and nitrogen sources were carried out according to Cowan (1974) and Pridham and Gottlieb (1966) respectively.

These isolates identified according to (Buchanan and Gibsons, 1974; Krieg, 1984 and Hensyl, 1994) Antibiogram Sensitivity:-

Antibiogram Sensitivity was performed using different chemotherapeutic agents the test was done according to method described with Quinn et al., (1994). Plant materials:

Shoot system (leaves and stems) of eugenia caryophllate wigare were collected from sienna south. Dried shoot system (leaves and stems) of eugenia caryophllate at room temperature. Powdered and kept in plastic bags until extraction.

\section{Screening for antibacterial activity:}

The antibacterial activity was determined according to Kavanagh (1972).

Extraction of plant materials:

The coarsely powered shoot parts of eugenia caryophllate (200 gms) were extracted. Extracted powdered with distilled water, 95 $\%$ ethanol and then partitioned using ethyl acetate and chloroform for 6 hours in a Soxhlet, then the extract was filtered using Whatman filter paper No. I after cooling. The excess solvent of crude and partition of aqueous and organic extract removed under vacuum using rotary evaporator. Each extract kept in refrigerator until further biological investigation. 
Precipitation.
precipitation antibacterial agent was carried out using petroleum ether. The compound precipitate was centrifuged at $5000 \mathrm{rpm}$ for 15 min. The antibacterial agent powder was tested for its antibacterial activity by using cup assay method" (Ueno et al, 2002).

Separation: "Separation of the antibacterial agent into its individual components has been tried by thin layer chromatography using a solvent system composed of chloroform and methanol (24:1, $\mathrm{v} / \mathrm{v})$ " (Kosar et al, 2004)

Purification: "The purification of the antibacterial agent was carried out by using Silica Gel Column Chromatography. A column of 2.5 $X 50 \mathrm{~cm}$ was used for this purpose. Chloroform and Methanol 10:1 (v/v), was used as an eluting solvent. The column was left for over night until the silica gel (BDH - 60- 120 mesh) was completely settled. One-ml crude extract to be fractionated was added on the silica column surface and the extract was adsorbed on top of silica gel. Fifty fractions were collected (each of 5 $\mathrm{ml})$. Antibacterial activities were performed for each separate fraction" (Sahin, 2004).

Physico-chemical properties of antibacterial agent.'

I- Eletnental analysis: The element analysis $\mathrm{C}, \mathrm{H}, \mathrm{O}, \mathrm{N}$, and $\mathrm{S}$ was carried out by the regional center for Mycology and Biotechnology Al-Azhar University, Egypt
2- Spectroscopic analysis: The GCmass techniques was determined at the regional center for Mycology and Biotechnology Al-Azhar University, Egypt.

Biological activity: The minimum inhibitory concentration (MIC) has been determined by cup method assay on the isolated microorganism.

\section{Results}

Results of Clinical examination of naturally infected $O$. niloticus' .

A Total Number of 200

Oreochromis niloticus were clinically examined and showed hemorrhages on several parts of the body surface (mouth, base of the fins, abdomen, opercula and around the anal opening), turbidity of the eyes and slight exophalima, roughness of the scales and Sometime scale losses occur as shown in photo (1) .

Results of postmortem examination of naturally infected O. niloticus:

The observed postmortem pictures were almost the same in all examined fish. These changes included congested, gills, hepatomegaly, splenomegaly, and distended gall bladder with bile, congestion of the kidney. Congestion and hemorrhages in intestine and bloody fluid accumulated in abdominal wall as shown in photo (2).

Results of bacteriological examination of naturally infected Orcochromis niloticus'. 
The results revealed the presence of different bacterial species which were either specific Fish pathogen including pseudomonas or other bacteria nonspecific fish pathogens including Pseudomonas and Aeromonas.

Identification of bacterial isolates: According to the cultured, morphological and biochemical characters; as shown in table-1; it was cleared that all bacterial isolates related to two bacterial genera and 2species (Pseudomonas aeruginosa-1;

Aeromonas hydrophila-2).

Control of pathogenic bacterial growth using eugenia caryophllate:

The antibacterial agent produced by eugenia caryophllate exhibited various degrees on pathogenic bacterial growth (Table 2), and (photo 3, 4)

\section{Antibiogram sensitivity test:}

The antipiogram sensitivity test revealed that:

1- Pseudomonas aeruginosa is sensitive to Amikan (AK) at a concentration of $(30 \mathrm{ug})$ and resistant to ciprofloxacin (CIP) at a concentration of (5 ug) and Neomycin $(\mathrm{N})$ at a concentration of $(30 \mathrm{ug})$,

2- Aeromonas hydrophila is sensitive to ciprofloxacin (CIP) at a concentration of (5 ug) and Amikan $(\mathrm{AK})$ at a concentration of (30 ug) and resistant to Neomycin $(\mathrm{N})$ at a concentration of (30 ug), as shown in Table-3, Table-4, and photo-5

Extraction, Precipitation and

\section{Purification of antibacterial activities.}

The different filtrates were tested for their antibacterial activity and it the best results obtained with ethyl alcohol extraction one as shown in table-5.

Crude deep brown powder was tested for their antibacterial activities by using cup diffusion method. The obtained results revealed that two band at $R_{\mathrm{f}} 0.76$; there is one band at $R_{f} 0.76$ exhibited obvious inhibitory effects against the growth bacterial strains.

The purification of the antibacterial agent was carried out by using silica gel column chromatography. The active fractions were concentrated. The maximum activity was recorded at fraction No. 9\&10 (Table 6).

Physico-Chemical

Properties of antibacterial agent.

The physical characteristics of the extracted ingredients showed a specific Physico-chemical properties such as melting point are $133^{\circ} \mathrm{C}$. Regarding the solubility the ingredients are soluble in ethanol, water, chloroform, DMSO and methanol but insoluble in petroleum ether, n-Butanol, hexane and benzene.

\section{A-Elemental analysis:}

This analysis indicates suggested empirical formula of the ingredient is $\mathrm{C}_{10} \mathrm{H}_{12} \mathrm{O}_{2}$

B- Spectroscopic characteristics: GC- mass techniques (Fig. 1). Area $=88.81 \%$ which indicates a suggested name Eugenol (phenol) 
(Fig 2).

C- Biological activities of the purified antibacterial Agent: Data of the antibacterial spectrum of antibacterial agent indicated that the antibacterial agent is fairly active against Gram negative bacteria (Table 7)

Table (1): The morphological, physiological and biochemical properties of the bacterial isolates:

\begin{tabular}{|c|c|c|}
\hline Characteristic & 1 & 2 \\
\hline \multicolumn{3}{|l|}{ Morphological characteristics } \\
\hline - Gram reaction & Negative & Negative \\
\hline - motility & + & + \\
\hline - Cell shape & Short rods & rods \\
\hline - Spore former & Non - spore former & Non - spore former \\
\hline - Diffusible pigment & Blue- green & yellow \\
\hline $\begin{array}{c}\text { Physiological characteristics: } \\
\text { A-Enzymes activity }\end{array}$ & 1 & 2 \\
\hline $\begin{array}{l}\text { Protein hydrolysis } \\
\end{array}$ & + & + \\
\hline Starch hydrolysis & - & - \\
\hline Lipid hydrolysis & + & + \\
\hline Egg - yolk (Lecithin) hydrolysis & - & - \\
\hline Oxidase test & + & + \\
\hline Catalase test & + & + \\
\hline \multicolumn{3}{|l|}{ B-Pigment production } \\
\hline Pyocyanin pigment & + & + \\
\hline Carotenoid pigment & + & + \\
\hline Fluorescent pigment & + & + \\
\hline \multicolumn{3}{|l|}{ Biochemical characteristics } \\
\hline -Degradation of Esculine & + & + \\
\hline -Gelatin liquefaction & + & + \\
\hline - H2S production & + & - \\
\hline - Nitrater reduction & + & + \\
\hline - Urea test & - & - \\
\hline - Indole production & - & + \\
\hline Levan formation from sucrose & - & - \\
\hline - Arginine dihydrolase & + & + \\
\hline $\begin{array}{l}\text {-poly } \beta \text {-hydroxy butyrate } \\
\text { accumulation }\end{array}$ & - & - \\
\hline - Utilization on $\mathrm{KCN}$ & + & + \\
\hline - Citrate utilization & + & - \\
\hline -Phenyl alanine deamination & + & + \\
\hline - Voges- proskauer test & - & + \\
\hline -Methyl red test & - & + \\
\hline Utilization of carbon sources: & 1 & 2 \\
\hline L- Arabinose & - & + \\
\hline D-Xylose & - & - \\
\hline D- Ribose & + & + \\
\hline D- Mannose & - & - \\
\hline
\end{tabular}




\begin{tabular}{|c|c|c|}
\hline Characteristic & 1 & 2 \\
\hline D-Glucose & + & + \\
\hline D-Fructose & + & + \\
\hline D-Galactose & - & + \\
\hline -Mannitol & + & + \\
\hline -Meso-Inositol & - & - \\
\hline -Sucrose & - & + \\
\hline -Maltose & - & + \\
\hline -Lactose & - & - \\
\hline -Raffinose & - & - \\
\hline -Trehalose & - & + \\
\hline -Melibiose & - & - \\
\hline- Starch & - & - \\
\hline Utilization of nitrogen source & 1 & 2 \\
\hline -Glycine & - & - \\
\hline L-Alanine & - & - \\
\hline L-Serine & + & + \\
\hline L-leucine & - & - \\
\hline L-valine & + & + \\
\hline L-lysine & + & + \\
\hline L-proline & + & + \\
\hline L-tyrosine & + & + \\
\hline L-Arginine & + & + \\
\hline $\begin{array}{l}\text { Growth in presence of different } \mathrm{NCl} \\
\text { Concentrations }(\%) \text { : }\end{array}$ & 1 & 2 \\
\hline 1 & + & + \\
\hline 3 & + & + \\
\hline 5 & + & - \\
\hline 7 & - & - \\
\hline Growth at different temperature $\left({ }^{\circ} \mathrm{C}\right)$ & 1 & 2 \\
\hline $20-40$ & + & + \\
\hline 41 & + & + \\
\hline
\end{tabular}

$+=$ Positive, $-=$ negative.

Table (2): Mean diameters of inhibition zones ( $\mathrm{mm}$ ) caused by $100 \mu$ of the antibacterial activities from eugenia caryophllate in the agar plate diffusion assay (The diameter of the used cup assay was $10 \mathrm{~mm}$ ).

\begin{tabular}{|c|c|}
\hline Test organism & $\begin{array}{c}* \text { Mean diameters of inhibition zones } \\
(\mathbf{m m})\end{array}$ \\
\hline Pseudomonas aeruginosa-1 & 30 \\
\hline Aeromonas hydrophila -2 & 25 \\
\hline
\end{tabular}

Table (3): Drug sensitivity test on Pseudomonas aerations

\begin{tabular}{|c|c|c|c|}
\hline $\begin{array}{c}\text { Antibiotics common } \\
\text { name }\end{array}$ & Concentration in ug & Biodise Code & $\begin{array}{c}\text { Mean diameters of } \\
\text { inhibition zones mm }\end{array}$ \\
\hline Amikan & $30 \mathrm{ug}$ & $\mathrm{Ak}$ & $\mathrm{S}$ \\
\hline ciprofloxacin & $5 \mathrm{ug}$ & $\mathrm{CIP}$ & $\mathrm{R}$ \\
\hline Neomycin & $30 \mathrm{ug}$ & $\mathrm{N}$ & $\mathrm{R}$ \\
\hline
\end{tabular}

$\mathrm{S}=$ Sensitive $\mathrm{R}=$ Resistance 
Table (4): Drug sensitivity test on Aeromonas hydrophila

\begin{tabular}{|c|c|c|c|}
\hline $\begin{array}{c}\text { Antibiotics common } \\
\text { name }\end{array}$ & Concentration in ug & Biodise Code & $\begin{array}{c}\text { Mean diameters of } \\
\text { inhibition zones } \\
\text { mm }\end{array}$ \\
\hline Amikan & $30 \mathrm{ug}$ & $\mathrm{Ak}$ & $\mathrm{S}$ \\
\hline ciprofloxacin & $5 \mathrm{ug}$ & $\mathrm{CIP}$ & $\mathrm{S}$ \\
\hline Neomycin & $30 \mathrm{ug}$ & $\mathrm{N}$ & $\mathrm{R}$ \\
\hline
\end{tabular}

$\mathrm{S}=$ Sensitive $\mathrm{R}=$ Resistance

Table (5): Extraction of antibacterial agents of Eugenia caryophllate

\begin{tabular}{|c|c|c|}
\hline \multirow{2}{*}{ Extract Type } & \multicolumn{2}{|c|}{ *Mean diameters of inhibition Zones (mm) } \\
\cline { 2 - 3 } & Pseudomonas aeruginosa-1 & Aeromonas hydrophila -2 \\
\hline Crude aqueous extract & 0.0 & 0.0 \\
\hline Ethyl acetate & 0.0 & 0.0 \\
\hline Ethyl alcohol & 30 & 25 \\
\hline Acetone & 0.0 & 0.0 \\
\hline Chloroform & 0.0 & 0.0 \\
\hline
\end{tabular}

Table (6): Isolation, precipitation and purification steps of antibacterial agent from eugenia caryophllate.

\begin{tabular}{|c|c|c|}
\hline \multirow{2}{*}{ Extract Type } & \multicolumn{2}{|c|}{ *Mean diameters of inhibition Zones (mm) } \\
\cline { 2 - 3 } & Pseudomonas aeruginosa-1 & Aeromonas hydrophila -2 \\
\hline 1-Isolation & $30 \pm 0.15$ & $25 \pm 0.22$ \\
\hline 2-Precipitation & $29 \pm 0.20$ & $24 \pm 0.25$ \\
\hline $\begin{array}{c}\text { 3-Purification by } \\
\text { Column } \\
\text { chromatography }\end{array}$ & $25 \pm 0.23$ & $20 \pm 0.17$ \\
\hline
\end{tabular}

Table (7): Antibacterial spectrum of the Purified antibacterial agent by applying the cup method assay.

\begin{tabular}{|c|c|}
\hline Test organism & MIC $(\boldsymbol{\mu g} / \mathbf{m l})$ concentration \\
\hline Pseudomonas aeruginosa-1 & 83.33 \\
\hline Aeromonas hydrophila $-\mathbf{2}$ & 83.33 \\
\hline
\end{tabular}

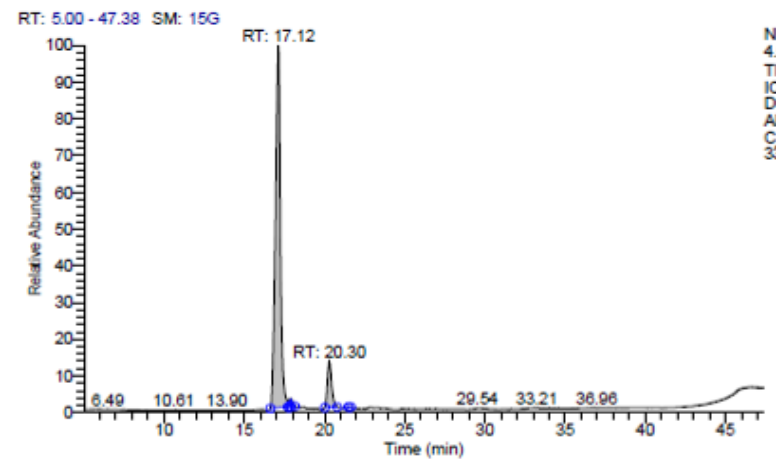

(Fig 1) GC- mass techniques-Area $=88.81 \%$ 


\begin{tabular}{|c|c|c|c|c|c|}
\hline RT & Compoid Nen & Aten $\%$ & Ara & Molectsy Foneds & Nolucist Tiket \\
\hline 17. & Erged & 8881 & 963301 & cIoth20: & 164 \\
\hline 17. & Suged & 8881 & 963301 & cicts:20? & 14 \\
\hline $\begin{array}{l}12 \\
17 \\
12\end{array}$ & 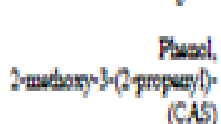 & $\$ 581$ & $\begin{array}{l}791618 \\
963301 \\
7916.18\end{array}$ & ciches:on: & 14 \\
\hline$\frac{17 .}{12}$ & 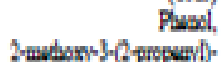 & $\$ \$ \$ 1$ & $\begin{array}{l}963301 \\
7916.18\end{array}$ & CICH:20: & 14 \\
\hline 17. & 2-mubon+4(- properyl) & \$\$.\$1 & 963901 & cict.20: & 144 \\
\hline
\end{tabular}

Hit Spectrom

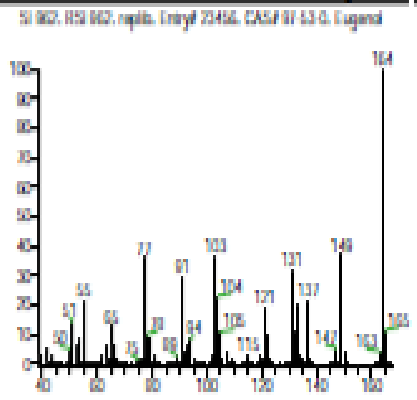

5) หล .

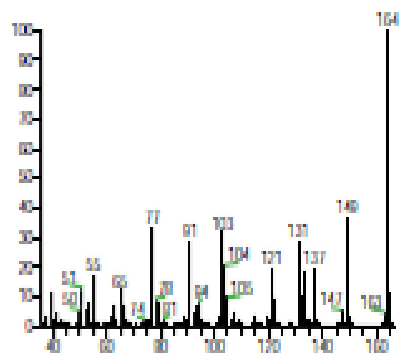

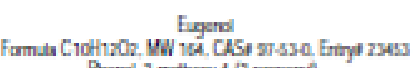
Avend, 2 -mathary 4 -12 propeny?-

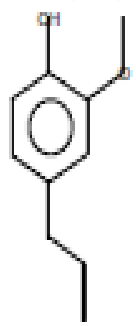

Puerol 2 matury 3 (2 proveryo- (CAS)

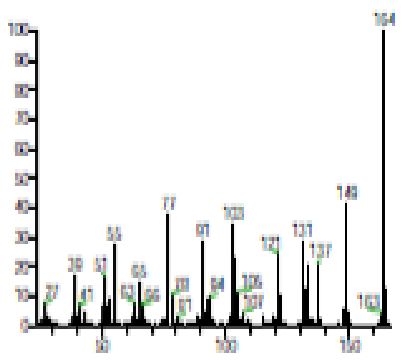

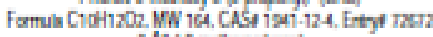

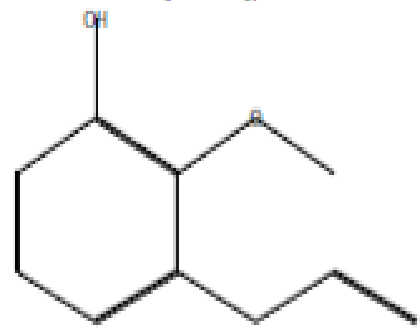

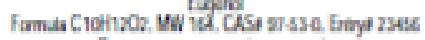

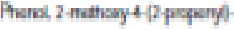

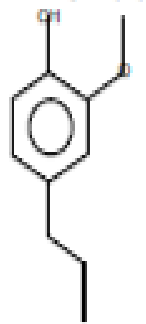



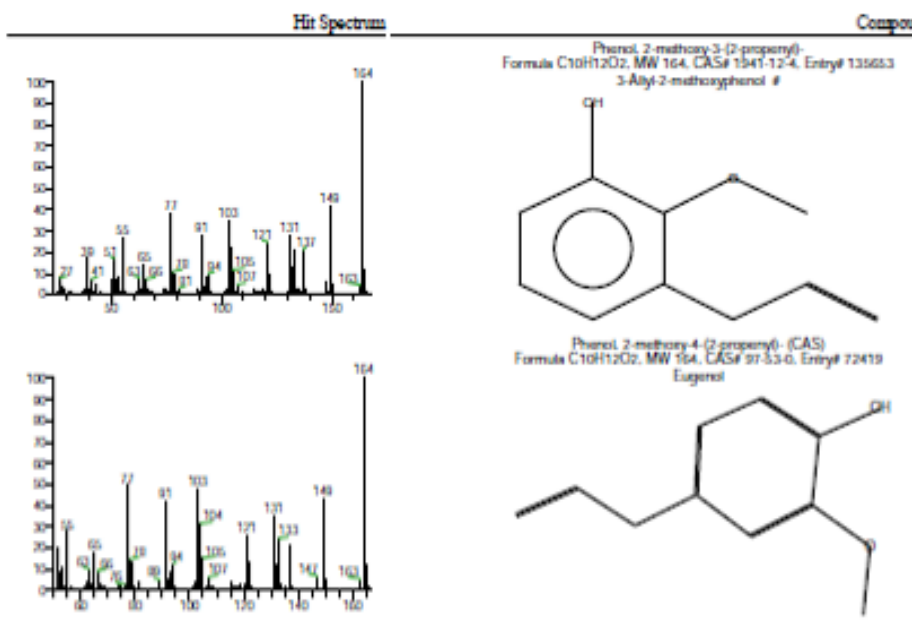

Conpound Structure

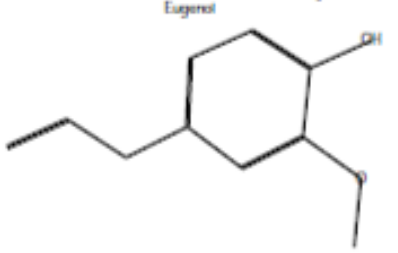

(Fig 2): Eugenol, phenol treatment and prevention fresh water fishes from bacterial diseases.

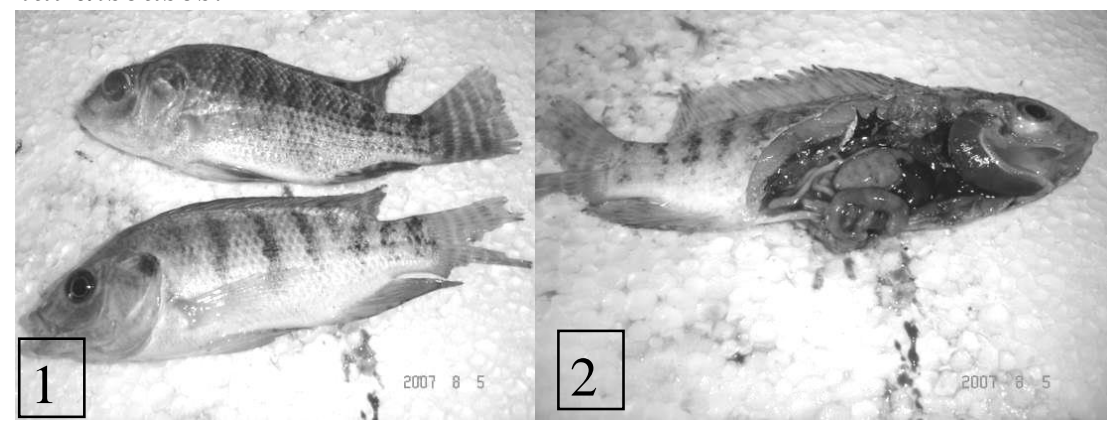

Photo (1) Clinical examination of naturally infected $O$. niloticus Photo (2) Postmortem examination of naturally infected $O$. nilaticus

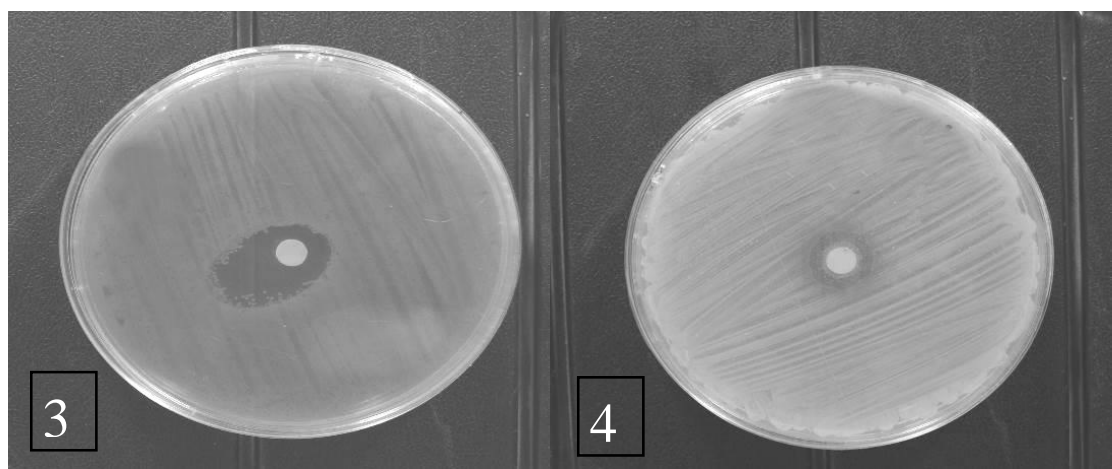

Photo (3) The antibacterial substance produced from eugenia caryophllate exhibited various degree of inhibition on Pseudomonas aeruginosa growth Photo (4) The antibacterial substance produced from eugenia caryophllate exhibited various degree of inhibition on A. hydrophila growth 


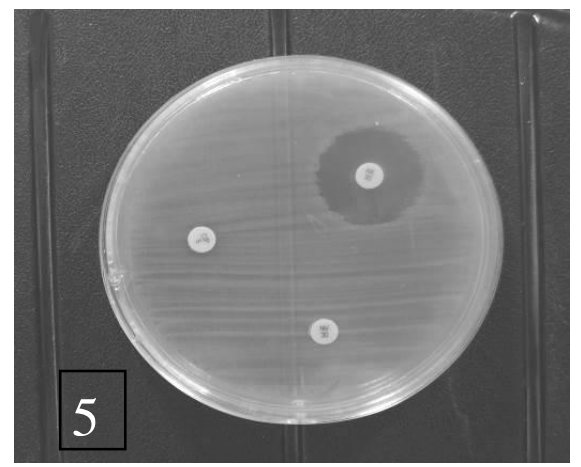

Photo (5) Drug sensitivity test

\section{Discussion}

Regarding the examination of naturally infected $O$. niloticus hemorrhages with Pseudomonas aeruginosia, and Aeromonas hydrophila humiliates all over body surface especially an the mouth, base of the fin, opercula, anal opening and turbidity and exophthalmia of the eyes this results were recorded with Marzouk et al., (1989), Badran and Eissa, (1991), Abd El-Rahman et al., (2002) and Abou El-Atta (2003). The observed gross lesions of affected fish showed that hepatomegaly, spleenomegaly, congestion of gills, kidney, distended gall bladder, congestion hemorrhage in the intestine and accumulation of bloody fluid is abdominal wall, these results observed by $\boldsymbol{A b \boldsymbol { d }} \boldsymbol{E I}$ Aziz, (1988) , Marzouk, (1989), ElAttar and Moustafa (1996), AbdRahman, (1996), Salama, (1999), Abd El-Rahman et al., (2002) \& Abou El Atta, (2003), Ali Aberoum,(2010) and Ye, (2013) and El- Didamoy, (2015). Pseudomonas aeruginosia, and
Aeromonas hydrophila considered the main isolates from diseased tilapia (o. niloticus) this results agree with Petrinee et al. (1985), Marzouk et al., (1989), Badran and Eissa (1991), Megahed, (2000), Haenen and Davidse, (2001), Abd El-Rahman el al. (2002) Abou El Atta (2003) and Samal, (2014). In last decades pseudomonas aeruginosa and hydrophilic are resistant to many antibiotics (Stojanov et al ., 2010 and Pannu et al., 2014), also results in table ( 3,4 ) showed that regarding to the antibiotic sensitivity of isolated pathogenic bacteria were resistant to Neomycin and were sensitive to Amikan these results are agreement with that finded by $\boldsymbol{A b o u} \boldsymbol{E l}$-Atta and Wafeek (2005), Rahman (2010) And Pannu (2014). For the purpose of the control of pathogen bacterial isolates, that used eugenia caryophllate. The coarsely powdered shoot parts of eugenia caryophllate $(200 \mathrm{gms})$ were extracted with $95 \%$ ethanol for 6 hours in a Soxhiet, then the extract was filtered using Whatman filter 
paper No. 1. Similar results were recorded by Anna Menaker et al. (2004) and Sivasankar (2015). The excess of crude extract evaporated under vacuum using rotary evaporator. The extract was concentrated and treated with petroleum ether (b.p. 40-60C) for Precipitation process where only one fraction was obtained in the form of deep brown ppt. Separation of antibacterial agent into individual components has been tried by thinlayer chromatography using a solvent system composed of chloroform and methanol (24:1, $\mathrm{v} / \mathrm{v})$ as developing solvent. The band with an $\mathrm{Rf}$ value of 0.76 there is one band at $\operatorname{Rf} 0.76$ exhibited obvious inhibitory effects against the growth bacteria strains. For the purpose of purification process, the antibiotic were allowed to pass through a column chromatography packed with silica gel and eluting solvent was composed of chloroform and methanol (10:1, $\mathrm{v} / \mathrm{v})$, fifty fractions were collected and tested for their activities. The maximum activity was recorded at fraction No. 9\&10. Similarly, many workers used a column chromatography packed with silica gel and an eluting solvent composed of various ratios of chloroform and methanol, which match with other finding Akihiko et al., (2000); Masao et al (2000); Naki et al. (2000); Oh-Sung et al., (2000); Toshio et al., (2000), Honda et al., (2001), Kenichi et al., (2001) Yoko et al.. (2001) and Ueno et al.
(2002). The

Physico-chemical characteristics of the purified antibacterial agents revealed that, the melting point are $133^{\circ} \mathrm{C}$ and soluble in ethanol, water, chloroform, DMSO and methanol but insoluble in, petroleum ether, n-Butanol, hexane and benzene. Similar results were recorded by Mitsunobu et al. (2000); Kenichi et al. (2001), Ueno et al. (2002), Anna, et al. (2004), Sahin et al. (2004) and Kosar et al. (2005). A study of the elemental analysis of the antibacterial agent lead to an empirical formula of: $\mathrm{C}_{10} \mathrm{H}_{12} \mathrm{O}_{2}$. The spectroscopic characteristics of antibacterial agent revealed the presence of the maximum absorption peak in GCmass techniques, area $=88.81 \%$ by Sahin et al., (2004) and Reverter (2014). The MIC of antibacterial agent under study exhibited various activities against gram negative bacteria. Similar investigations and results were attained by Kilbum et al. (2000); Morrissey and George (2000); O'Donnell and Gelone (2000); Oethinger et al. (2000); Okuda et al. (2000); Lomovskaya et al. (2001), Pan et al. (2002) and Atta, et al. (2003) Sahin, et al. (2004) Kosar, et al. ( 2005), Sivasanker (2015) and ElDidamoy (2015).

\section{References}

Abd El-Rahman, AM. (1996): "Studies on bacterial diseases among cultured Tilapias." M. Sc. Thesis (Fish diseases and 
Mangement). Faculty of Vet Med. Suez Canal University.

Abd El- Rahman, AM.; ElNoU,G. Ahmed and Moustafa, .4. (2002): Studies on Pseudomonas septicaemia among Tilapia fish in Abbassa fish faim. Zag. Vet J. 30 (1), 25-31.

Abd Et-Aziz, E.S. (1988): 'Some studies on bacterial agents causing tail and fin rot among fash water fishes in Egypte" M.Sc. ITiesis (Infections diseases) faculty of Vet. Me. Cairo University.

Abouelmaatti, R. R., Algammal, A. M., Li, X., Ma, J., Abdelnaby, E. A. and Elfeil, W. M. Cloning and analysis of Nile tilapia Toll-like receptors type-3 mRNA. - Central European Journal of Immunology 38: 277-282.

Abou Et-Atta, M. EI-S.I. (2003): Efficiency of polyroerase chain reaction PCR" in diagnosis of some Bacterial Fish Pathogens Ph.D. Thesis (microbiology) Fac. Of Vet Med., Suez Canal University

Abou El-Atta and Wafeek (2005):" Effect of water temperature on appearance of bacterial diseases and their reflection on biochemical changes in Oreochromis niloticus at Damietta branch of the river Nile. Egypt. J. Aquat Biol. \&Fish. Vol 9.No4. 353- 366.

Ahmed, Sh. M. and Shoreit, A. (2001): "Bacterial haemonhagic septicemia in Oreochromts niloticus at Aswan fish hatcheries" Assiut Vet. Med. J. Vol. 45 No. 89, April 2001.
Akihiko, F.; Toshiro, L; BUcyttIa, 11.; Terami, 0.; Kumiko, N.; Tomoka, N.; Knutoshi, S.; Yusuhlra, H.; Motohiro, H.; SeiJi, H. and Mmalfuni, 0. (2000): FR901469, a Novel Antifimgal Antibiotic fiom an Unidentified Fungus No. 11243: I- Taxonomy, Fermentation, Isolation, Physico-Chemical Properties.J.of antibiotics.Vol.53 (9): 912-919.

Ali Aberoum and Hossein Jooyandeh. (2010): Review on Occurrence and Characterization of the Aeromonas Species from Marine Fishes World Journal of Fish and Marine Sciences 2(6): 519 -523 ).

Aligiannis, N.; Kalpoutzakis, E.; Mitaku, S. and Chinou, I.B. (2001): Composition and antimicrobial activity of the essential oils of two eugenia caryophllate species. Journal of Agricultime Food Chemistry. 49:4168-4170.

Ammar, M.S.; EI-Lcuboudy, S.S. and Abdul- Raalif, V.M. (1991): Purification and Properties of mesophilic protease(s) produced by Bacillus anthracis, S-44. Isolated from a temple in Aswan. Al- Azhar Bull. Sci., Vol. 2(1): 325338.

Ammar, M.S.; El-Oamut, UI.S. ; El- Louboudf, S.S. andibrahim, AM. (1995): Fermentation of mesophilic proteases by B.subtilis, $\mathrm{S}-19$ m relation to certain nutritional factors under solid state fermentation in relation to vitamins, 
amino acids, heavy metals and certain plant growth regulators, $r$ Intern. Coirfr. (Sci. and developm.) Cairo 20-23, March (1995).

Ammar, MS.; EL- Esmoey, M.; Yassin, M. anil Shmf, Y.M. (1998): Hydrolytic enzymes of fungi isolated from certain Egyptian Antiquities objects while utilizing the industrial wastes of Sugar and Integrated Industries Company (SIIC). Egypt. J. Biotechnol., Vol. 3. Jan. 1998: PP. 60 - 90.

Anna, M.; Marina, K; Mihiuil, J. and Anne, 0. (2004): Identification and characterization of supenritical fluid extracts from herbs. C.R. chimie 7 (628-633).

Atta, H.M.; Abul-Bamd, A.T. and Zain, M.E. (2003): Fennentation, Extraction, Physicochemical Properities and Biological activities of the antifungal agent produced by Streptomyces aureofaciens. The African journal of mycology and biotechnology. Vol. 11(2) August: pp 51-67.

Badran, A.P. and Khua, I.A.M. (1991): "Studies on bacterial diseases among cultured Freshwater fish (Oreochromis niloticus) in relation to incidence of bacterial patbogens at Ismailia Govemorate". J. Egypt. Vet .Med. Ass. 51 (4), 837-847.

Buchanan, IC.E. and GUbson, N.E. (Ed.) (1974): Bergey's Manual of Determinative Bacteriology $8^{\text {th }}$ edition. The Williams \& Wilkins Company/
Baltimore.

Chandler, S.F. and Dodds, I.H. (1983): The effect of phosphate, nitrogen and sucrose on the production of phenolics and solasidine in callus cultures of Solanum lacinitum .Plant Cell Reports, 2,105.

Cowan, S.T. (1974): Cowan and Steels Manual For The identification of Medical Bacteria 2nd. Edition Cambridge, Univ. Press.

Dean, S.O.; Smboda, K.P.; Gundidia, M. and Brechany, B.Y. (1991): Essential oil profiles of severe temperate and tropical aromatic plants: their antimicrobial and antioxidant activities. Acta Horticulture.306:229 - 232.

Eid, H.I., Algammal, A.M., Nasef, S.A., Elfeil, W.K., and Mansour, G.H. 2016. Genetic variation among avian pathogenic E. coli strains isolated from broiler chickens. Asian Journal of Animal and Veterinary Advances 11(6): 350-356. doi: 10.3923/ajava.2016.350.356.

El-Attar, A.A. and Moustafa, M. (1996): "Some studies on tail and fm rot disease among cultured Tilapia Fishes. "M.Sc. Thesis (Infections diseases) faculty of Vet. Me. Cairo University.

El-Didamony Gamal. Selim M Khaled; El-Araby DoaaA. And Megahed. Th .Marihan (2015) Effect of Cichoriumitybus on mmun status and Aeromonas hydrophhiladisease resistance $\mathrm{pf}$ Orechromis niloticus .Science 
journal.

Elfeil, W.K., Abouelmaatti, R.R., Sun, C.J., Han, W.Y., Li, X.K., Ma, J.S., Lei, L.C., Liu, S.S., Yang, Y.J., Wang, Y., Mandour, M., Fawzy, M., and Shalaby, M.N. 2012. Identification, Cloning, Expression of a Novel Functional Anas platyrhynchos mRNA TLR4. J Anim Vet Adv 11(10): 17271733.

Elfeil, W.M.K., Algammal, A.M., Abouelmaatti, R.R., Gerdouh, A., and Abdeldaim, M. 2016. Molecular characterization and analysis of TLR-1 in rabbit tissues. Central European Journal of Immunology 41(3): 236-242. doi: 10.5114/ceji.2016.63121.

Elwan, S.H.; Et-Nagar, M.X. and Ammar, M.S. (1977): Characteristics of Lipase(s) in the growth filtrate dialystate of Bacillus stearothermophilus grown at $55^{\circ} \mathrm{C}$ using a tributryin- cup plate assay. Bull. Of the Fac. Of Sci Riyadh Univ., vol.8: 105- 119.

Gittino, P. (1976): "International aspects of disease control in aquaculture." FAO Technical conference on aquaculture. Kyoto, Japan. 26 May- 2 June.

Haenen, O.L. and Davidse, A. (2001): First isolation and pathogen city studies with pseudomonas anguilliseptica from diseased European eel Anguilla (L.) in the Netherlands. Aquaculture. 169:27-36.

Hensyl, W.R (1994): Bergey's Manual of Systematic Bacteriology 9th Edition. John. G,
Holt and Stanley, T. Williams (Eds.) Williams and Wilkins, Baltimore, Philadelphia, Hong Kong, London, Munich, Sydney, Tokyo.

Hondo, Y.; Ueki, M.; okada Onose, R.; Usami, R.; Horlikoshi, K. and Osada, $\mathrm{H}$. (2001): Isolation, and biological properties of a new cell cycle inhibitor, curvularol, isolated from Curvularia sp. RK97-F166. J, Antibiot. 54:10-16.

Kenichi, K.; Ryosuke, F., Toshiyuki, K.; Keisuke, T.; Yoshihiro, S.; Makato, o. and Yauji, S. (2001): New cyclic Depsipeptide antibiotics , Clavariopsin A \& B Produced by an aquatic

Clovariopsis aquatica 1Taxonomy, Fermentation Isolation and Biological Properties. J. of antibioitics. 54 (1): 17-21.

Kilburn, L.; Downar, J. and Tong, B. (2000): Norfloxacin, Moxifloxacin and gatifloxacin preferentially target GyrA in Streptococcus pneumoniae. Presented at the 40th interscience conference on antimicrobial agents and chemotherapy, Toronto, Ontario) Canada, September 17-20.

Kosar, M.; Dormant H, and Hiltunen, R. (2005): Effect of an acid treatment on the phytochemical and antioxidant chaiacteristics of extracts from selected Lamiaceae species. Food Chemistry 91, (525-533). 
Krieg, N.K. (1984): Bergey's Mannal of Systematic Bacteriology, Vol.I, Baltimore, Hong Kong, London, Sydney.

Lomovskaya, O.; Warren, M.S., and Lee, A. (2001): Identification and characterization of inhibitors of multi-drug resistance efflux pumps in Pseudomonas aeruginosa: novel agents for combination therapy. Antimicrob Agents Chemother; 45:105-16.

Marzouk, M.S.; Eissa, I.A. M; Moustafa, M, and Mervat, S.H. (1989): Contribution to tail and fin rot disease in catfish (Clarias lazara). Zag. Vet. J. Vol. 17 No. 3P. 244- 257.

Masao, T.; Shigeru, N.; Kumiko, M.;' Minoru, N; Hajime, S.; Mioko, H.; Kaori, H.; Katsuhisa, K. and hirouki, S. (2000): New Cytotoxic agents, BE-52440 A and B, Produced by a Streptomyce. J. of antibiotics. 53 (7): 687 - 693.

Megahed, A.A. (2000): Studies on some Gram negative bacteria of fish M.Sc. Thesis (microbiology) Fac. Of Vet Med. Suez Canal University.

Milos, M.; Mastelic, J. and Jerkavic, 1. (2000)! Chemical composition and antioxidant effect of glycosidically bound volatile compounds from oregano Origanum vulgare L.ssp.hirtum .Food Chemistry. 71:79-83.

Mitsunobu,H.;Shiro, S.;Nikito, L; Kenzo,S.; Jun, E.and Tamio,M.(2000):UCF-116,New inhibitoies of Farnesyltransferase produced by Streptomyces sp, J. of antibiotics, 53 (7) : 720 - 723.

Morrissey, 1. and George, J.T.(2000): Activity of gemifloxacin and other fluoroquinolones against DNA gyrase and topoisomerase IV ftom Haemophilus influenzae. Presented at the $40^{\text {th }}$ interscience conference on antimicrobial agents and chemotherapy, Toronto, Ontario, Canada, September 17-20.

Naki, N.; Jun, K.; Masaakti, S.; Shin- Ichi, S., Nobuaki, 0.; Kimo, K. and Naruse, N.; Tenmyo, O.; Koburu, S.; Hatori, M.; Tamito, K.; Hamagishi, Y. and Oki, T. (2000): New antiviral antibiotics, Kistamicins A and B 1Taxonomy, production, isolation, physico-chemical properties and biological activities. J. of antibiotic. 46 (12): 1804-1811.

Nitsh, B. and Kutzer, H.J. (1969): Egg-Yolk agar as diagnostic medium for Streptomyces. Sp 25:113.

O'Dannell, J.A. and Gelone, SP*. (2000) Fluoroquinolones. Infect Dis Clin North Am; 14:489-513.

Oethinger, M.; Kernw, W.V; Jellen- Ritter-, A.S.; McMurr, L.M. and Levy, S.B. (2000): Ineffectiveness of topoisomerase mutations in mediating clinically significant fluoroquinolone resistance in Escherichia coil in the absence of the AcrAB - efflux pump. Antimicrob Agents Chemother; 44:1013.

Oh-Sung, K.; Sang, H.; Bong-Sik, Y; Yy-Rang, P. and Chang, $K$. (2000): Cyclo (Dehydroala-L- Leu) 
an a-Glucosidase inhibitor from Penicillium sp. F70614. J. of antibiotics. 53(9): 954-958.

Okuda J.; Onodera, Y. and Tanaka, M. (2000): Dual inhibitory activity of sitafloxacin against DNA gyrase and topoisomeiase IV of Enterococcus faecalis and Streptococcus pneumoniae. Presented at the $40^{\text {th }}$ interscience conference on antimicrobial agents and chemotherapy, Toronto, Ontario, Canada, September 17-20.

Okpk warsiill, G.C. anil Obaho, O.O. (1991):'Relationship betwe water quality and bacteria. Associated with the brown. Patch disease of Tilapia fingerlings reader in tropical fresh water, culture ponds."J. of Aquacu. In theTiopics. 6:2,157-172.

Pan, X.S.; Hamlyn, P.J.: TalensVisconti, R.; Aloverio, F.L.; Manzo, R-H. and Fisher, LM. (2002): Small-Colony Mutants of Staphylococcus aureus Allow Selection of Gyrase-Mediated Resistance to Dual-Target Fluoroquinolones. Antimicrob. Agents Chemother. 46:2498-2506

Pannu, R.; Dhiya, S.; Sabhlok V.P.; Kumar D.' Sarsar, V.and Gahlawat, S.K. (2014): Effect of probiotics, antibiotics and herbal extracts against fish bacterial pathogens.Ecotoxicol. Environ Contam, 9 (1): 13- 20

Petrinee, Z.; Naglic, T.; Matasin, Z. and Fijan, N. (1985): "Pseudomonas fluorescens septicemia in big head
(Aristichthy nobilis rich), following handlings Veterinarshi, Arhiv, 55 (6), 277- 284.

Pridham, T.G. and Gattlieb, R.G. (1966): A section of media for maintenance and taxonomic study of Streptomycetes. Antibiotics Ann. pp. 947-953.

Quinn P. J., M.E.Carter, B.E. Carer B., K. Markeu and G.R Carter 1999. Clinical veterinary Microbiology published by Wolf Publishing, Book Europe Limited.

Rahman, M.M. and Hossain. M.N. (2010): antibiotic and herbal senitivity of some Aeromonas sp. Isolates collected from diseased CARP fishes Progress Agric. 21 (1 \& 2): 117-129

Reverter M, Bontemp. N.Lecchini D., Banaigs B., Sasal P. (2014) Use of plant extracts in fish aquaculture as an alternative to chemotherapy: Current status and futures perspectives. AAquaculture 43350 -61 .

Robertson, P.A.W.; Odowd, C.; Williams. P. and Austin, B. (2000): Use of Carnobacterium sp. As a probiotic for atlantic salmon (Salmo salar) and rainbow trout Oncorthyncus mykiss (Walbaum) Aquaculture, 185: 235-243.

Sahin, F.; Goluce, M.; Daferera, D.; Sokmen, A.; Sokmen, M.; Polissiou, M.; Agar G. and Ozer, H. (2004): Biological activities of the essential oils and methanol extract of origanum vulgare ssp. vulgare in the Eastern Anatolia region of Turkey. Food Control 15; (549-557). 
Salama, S.S. and Abd El-Aziz, H. (1999): Studies on the bacterial diseases of Oreochromis niloticus reared in concrete pond. M.V.SC. Thesis (Fish Diseases and Management) Fac. Vet Mod. Suez Canal Univ.

Samal Kanta Surya, Das Kumar Bassants and Pal Bhusa Bibhuti . (2014):

Isolation biochemical characterization, antibiotic susceptibility study of Aeromonas hydrophial isolated from freshwater fish, nt J.Curr. Microbial App. Sci 3 (12): $259-267$.

Schapercluas FT.; kulow, $H$ and schreckenback K. (1992): Fish Disease Voli A.A. Balkema / Rotterde.

Sivasankar P, Anix Vivek Santhiya A, Kanaga V. (2015): A review on plants and herbal extracts against viral diseases in aquaculture Journal of Medicinal Plants Studies. 3(2):75-79

Slinkard, $K$ and Singleton, V.L (1997): Total phenol analyses automation and comparison with manual methods. American Journal of Enology and Viticulture, 28:49-55.

Stojanov, I.; Plavsa, N'. Stojanovic D., RATAJAC, Radulovic, L.P.; Pusic, I. and Kapetanov M. (2010):
Suceptibility of Aeromonas hydrophila isolates to antimicrobial drugs. Lucraristiintifice Mediina Veterinara, 43 (1): 132- 136

Toshio, o.; Yoshikazu, S.; Yoshimi, A. Yasuhiro, I; Tamotsu, F.; Nonriko, S.; Yuji, Y.; tetsuji, A. and Toshikazy, $O$. (2000): New cdc 25B Tyrosine phosphate inhibitors TP-A0248: Taxonomy, Fermentation, Isolation, Structure elucidation and Biological properties. J. of antibiotics. 53(4): 337-344.

Ueno, N.; Urano, N. ; Suzuki , M and Kimura; S. (2002): Isolation, characterization, and fennentative pattern of a novel thermotolerant Prototheca zopfii var. hydrocarbonea strain producing ethanol and $\mathrm{CO} 2$ from glucose at 40C. Arch. Microbiol. 177:244-250. Williams, S.T. and Davies, F.L. (1965): Use of antibiotics for selective isolation and enumeration of actinomycetes in soil. J. Gen. Microbiol., 38:251-262.

Yoko., H.; Masashi, U.; Gen, O.; Rie, O.; Ron, U.; Koki, H. and Hikoyuki, O. (2001): Isolation and Biological properties of a new cell cycle inhibitors curvularol, Isolation from curvularia Sp RK97F166.J. of antibiotics. 54 (1): $10-$ 16 